\title{
Literatura y memoria: espacios de subjetividad*
}

\author{
Susana Ynés González Sawczuk** \\ Yobenj Aucardo Chicangana-Bayona**
}

\begin{abstract}
Resumen
Se parte de una actualización teórica y de una semblanza del estado del arte de la crítica y de la teoría literaria para dar cuenta del estatuto de la ficción. En otro momento, se intenta dialogar con obras que propician la exploración a través de diferentes variantes y actitudes de una voz y de una perspectiva del relato que conmina a un diálogo de confesión identitaria. Se trabajará con novelas de Martín Kohan, Laura Restrepo y Luisa Valenzuela, entre otros, la idea es atender la variedad de registros y desplazamientos ilusorios de narradores que se dan como contrapunto, en diferentes modalidades de la representación del pasado, con otras prosas latinoamericanas. Interesa problematizar los dispositivos en juego para traer lo vivido y para mirar hacia atrás entre la rememoración y el olvido.
\end{abstract}

Palabras clave: Literatura y memoria, autoficción, testimonio, sedimentos culturales.

\section{Literature and Memory: Spaces of Subjectivity}

\begin{abstract}
Become part of a theoretical update and of a biographical sketch of the state of the art in critique and literary theory in order to account for the statute of fiction. At another moment, we try a dialog with works that provide exploration through different variants and attitudes of a specific voice and a perspective of the story that imposes a dialog of identity confession. We will work with the novels of Martín Kohan, Laura Restrepo and Luisa Valenzuela, among others. The idea is to attend the variety of registers and imaginary movements of narrators that are given as a counterpoint, in different modalities of the representation of the past, along with other Latin-American prose. It is of interest to problematize the mechanisms at play in order to bring forth what has been lived and to look back between remembrance and obscurity.
\end{abstract}

Key words: Literature and memory, autobiographical, testimony, cultural sediments.

Recibido: 06-03-2013 Aceptado: 18-07-2013

* El presente texto forma parte de la investigación: "Literatura y Espacios de Subjetividad" del Grupo de Estudios Estéticos y del proyecto "Fortalecimiento de grupos de investigación que soporten programas de posgrado de la Universidad Nacional de Colombia (2012). Grupo Historia, Trabajo, Sociedad y Cultura". Código 16093.

** Argentina, Doctora en Letras de la Universidad de São Paulo (USP), Brasil. Diplomada Superior en Ciencias Sociales, FLACSO - Sede Argentina. Profesora Titular del Departamento de Estudios Filosóficos y Culturales, de la Universidad Nacional de Colombia-Medellín. Sus intereses temáticos abarcan la literatura latinoamericana, retóricas del cuento, ficción y crítica, y espacios de subjetividad.sigonzal@unal.edu.co

*** Colombiano, Doctor y Magíster en Historia de la Universidad Federal Fluminense (UFF), Brasil. Profesor Titular del Departamento de Historia, de la Universidad Nacional de Colombia-Medellín. Sus intereses temáticos abarcan las Ciencias Humanas, los Estudios Visuales y la memoria. yachican@unal.edu.co 


\section{La ficción-objeto, de discusión}

Hablar de la literatura como otra de las expresiones artísticas siempre es una afirmación que incomoda. Menos problemático es situarla en el ámbito de la comunicación, como espacio abierto de entretenimiento y dimensión que refleja creencias, ideologías, tributaria de lo históricosocial o de alguna concepción dominante, que carga valores impolutos sólo por la intención de quien quiere dar cuenta de pasiones, de ideas, de vidas. Es decir, no es ni buena ni mala, es otra manifestación que resiste cualquier valor estético, pero que sí se acopla a consideraciones de otras configuraciones discursivas. Desde estas perspectivas, que abundan incluso en el medio académico, la literatura da para todo, menos para asentar su autonomía y su extraordinaria capacidad de transformación y transfiguración del hombre y del mundo. En la siguiente reflexión nos disponemos a desandar este último recorrido de interpretación. Nuestro punto de partida en la cita continua, pretende -también- ser el lugar de desenlace, de conclusión de la argumentación, es decir, partimos de una afirmación a la que queremos llegar con este razonamiento.

En un breve ensayo, "La narración-objeto" (1999), el escritor argentino Juan José Saer sienta una premisa visionaria al afirmar que "la ficción narrativa comercia con la filosofía. [..] de manera implícita o explícita, la noción de objeto está en el centro de todo relato de ficción" (17), y en líneas siguientes avanza más en este razonamiento, "cuando finge que es verdadera, la ficción finge una realidad no de discurso, es decir de una concatenación de universales, sino de objeto, o sea una organización singular de objetos particulares" (19-20). Bien, a partir de aquí, tal vez podamos guiar esta disertación pensando en la siguiente cuestión ¿qué significa hablar de literatura?, entendiéndola como narrativa de ficción.

En principio, se tratará de recuperar algunos elementos que definen el estatuto de la ficción. La ficción es diégesis (relato), igual que la historia, pero por sobre todo es poiesis (creación) y desde La Poética de Aristóteles, que la diferencia de la retórica, es el arte de la imaginación que instala lo verosímil (arte de la apariencia), lo que parece ser y no es, lo posible según la verosimilitud o la necesidad, donde el mundo inmanente se hace real. Según Aristóteles, "no corresponde al poeta decir lo que ha sucedido sino lo que podría suceder, esto es, lo posible según la verosimilitud o la necesidad" (García Yebra, 1974: 157), y este arte de la imaginación opera por la mimesis, que es actividad creadora o como la define Aristóteles, 
imitación creadora. Entonces, como creación, como representación otra que es la poética, dos sentidos se condensan, el sentido metafórico de la ficción (diégesis) y el poder operante que tiene el relato de ficción al revelar la realidad como acto (representación, creación otra).

Siguiendo en esta línea, sirven las reflexiones del crítico literario Noé Jitrik quien, en su ensayo: Historia e imaginación literaria. Las posibilidades de un género (1995), desde una perspectiva centrada en el lenguaje y en relación con la dinámica y el procedimiento que instala la ficción, recupera la etimología del término referir, del verbo: refero (latín) que significa "volver a traer" (de esa raíz también surgen transferir, diferir, referencia); y la otra acepción que carga es la forma no personal: relatum (relato). Si pensamos que toda creación ficcional parte de un referente (real/referencial) y que, por mediación del lenguaje, se crea la otra instancia, el referido (representación literaria) y, siguiendo a Jitrik, en un mismo procedimiento se implica no sólo qué se refiere (refero: volver a traer), sino cómo lo refiere (relatum: relato), es decir, cuál es el sistema de referencia, y cómo es esa mediación creativa del lenguaje (Jitrik, 1995: 15). De acuerdo con lo expuesto y retomando a Aristóteles, se puede afirmar que en la misma aplicación de la actividad creativa de la mimesis se vuelve a traer, en un nuevo relato, las cosas en acto.

En obras más actuales y en diferentes trabajos, el filósofo Paul Ricoeur (1983-1987-1996), desde un enfoque hermenéutico da continuidad a esta línea de reflexión y vuelve a poner en la mira conceptual las categorías propias de todo relato: la identidad narrativa, la dimensión lingüística del relato, la dimensión temporal como mediación del discurso, entre el tiempo histórico y el real ficcional y la filosofía del sí mismo, con sus dos caras, el idem y el ipse; en fin, todos espacios de reflexión indispensables para cualquier modalidad de escritura autobiográfica. Se actualizan así y cobran fuerza, en tiempos de difusión de las narrativas del yo, las variantes conceptuales que interjuegan en la creación ficcional. Y en tanto que, no se trae al objeto sino una representación mental del objeto, se refuerza la premisa de que "la orientación referencial del lenguaje es indirecta" (Klein, 2008: 17), así el lenguaje no reproduce, produce significación. El punto de anclaje lo encuentra Ricoeur en el proceso de refiguración, la figura, entonces, la imagen, podemos decir que es la activadora de esos traslados del lenguaje. Así la lectura es la actividad que vuelve inteligible el proceso, y es en esa recuperación final donde cobra sentido este devenir replicado porque se vincula la trama con la figura 
productora de sentidos; en fin, estos momentos se implican mutuamente, y la mímesis resulta una especie de metáfora de la realidad, precisamente, a la que activa (Klein, 21). Con su interpretación, volvemos a reforzar el carácter tropológico del discurso: la metáfora (recordemos, una de las implicancias en La poética, "sentido metafórico de la creación de la imaginación"), en fin, simplificando en estos procesos, todo empieza y termina con el reconocimiento de la figura.

Otros aspectos atienden a la identidad subjetiva y a la enunciación, para lo cual Ricoeur dialoga con Bajtín y diferencia, también, el enunciado que es "el qué refiere", de la enunciación que atiende al "cómo lo refiere". Para Ricoeur la identidad se constituye en el relato, ya que "narrar es decir quién ha hecho qué, por qué y cómo, desplegando en el tiempo la conexión entre estos puntos de vista" (1996: 146). Su reflexión actualiza la problemática del estatuto de la identidad narrativa, de acuerdo a la relación dialéctica que queda imbrincada en el doblez que carga el sí mismo, "como idem (idéntico, sumamente parecido, inmutable, que no cambia con el tiempo; y como ipse (propio, opuesto a lo otro, a lo extraño, con permanencia problemática en el tiempo)" (Camarero, 2011: 72), así la identidad se funda en ese interjuego, en la idea de un sujeto reflexivo, dialógico, diferente de un sujeto sustancialista (que reposa sobre lo idéntico), sino un sujeto atravesado por otro, mediado por símbolos, lenguajes, relatos y constituido por el tiempo, así como nos aclara Irene Klein, "toda narración es el resultado de la dinámica de lo concordante / discordante, entre lo que media la configuración. Es a partir del arte de componer, mediante la síntesis de lo heterogéneo, que la dispersión episódica del relato obtiene unidad" (27).

Por último, y tratando de recuperar la premisa inicial, la literatura es más que lenguaje, es el espacio de reconocimiento de todas las mutaciones sociales, concatenación singular, de objetos particulares, de atributos, que cifran el mundo. Para el maestro, de maestros Alfonso Reyes: el fenómeno literario es fenomenografía, "donde cada ente literario está condenado a una vida eterna, siempre nueva y siempre naciente, mientras viva la humanidad" (1989: 73).

\section{Cómo capturar la experiencia en el relato}

En las ciencias sociales son frecuentes los discursos que destacan y privilegian aquellos relatos de testimonios de vida, de experiencias 
de dolor, de representaciones de lo cotidiano, que colocan al lector en la inmersión de una intimidad para reconstruir sentidos sociales. La literatura propicia la exploración a través de diferentes variantes y actitudes de una voz y de una perspectiva del relato que conmina a un diálogo de confesión identitaria. Es otra literatura que trabaja con el ejercicio de la lengua crispada en los límites entre lo dicho y lo no dicho, son relatos que hacen ver y traen "el pasado como temporalidad 'en proceso' de construcción" (Saraceni, 2008: 29). Textos que trabajan en un borde entre lo biográfico y lo social, lecturas que pretenden acercar con la representación la verdad de una experiencia, incluso como paradoja del habla de un sujeto ficticio y de los desplazamientos inevitables ante cualquier intento de autorrepresentación. Relatos que manifiestan cómo, a pesar de las dispersiones que se dan en la escritura y que dan cuenta de la dificultad al pretender hacer materia de la ficción historias individuales o situaciones de experiencias propias, se logra la impronta de representaciones literarias donde se leen registros de una vida y de una época.

Nos interesa problematizar la variedad de registros y desplazamientos ilusorios de narradores, el uso del "sí mismo como otro", las diferentes modalidades de la representación del pasado y los dispositivos en juego para traer lo vivido, para mirar hacia atrás entre la rememoración y el olvido. Sin perder de vista que, como señala Alfonso Reyes, "el contenido de la literatura es, pues, la pura experiencia, no la experiencia de determinado orden de conocimientos. [Sino] La experiencia contenida en la literatura" (1989: 71). En este segmento de análisis priorizamos textos que se limitan a momentos puntuales, marcados por masacres y represión, otros por la censura y el horror de la última dictadura en Argentina en los setenta, que tienen a Buenos Aires como escenario de una ciudad sitiada por el miedo, y hacen de la memoria el espacio de recuperación de historias de vida que han sido silenciadas.

Las apreciaciones críticas coinciden en calificar a los tiempos actuales como "una época memorial" (Sarlo, 2006). Desde múltiples espacios se replican significantes e imágenes que intentan rescatar las marcas de una experiencia aterradora. La literatura, entre esa diversidad de registros, se acopla al sostener el testimonio y otras formas de discurso autobiográfico como las variantes que insisten en "el empeño de hacer presente lo que está ausente" (Arfuch, 2008: 163). Las marcas de vivencias personales, historias de vida al modo de confesiones, se ponen al descubierto en 


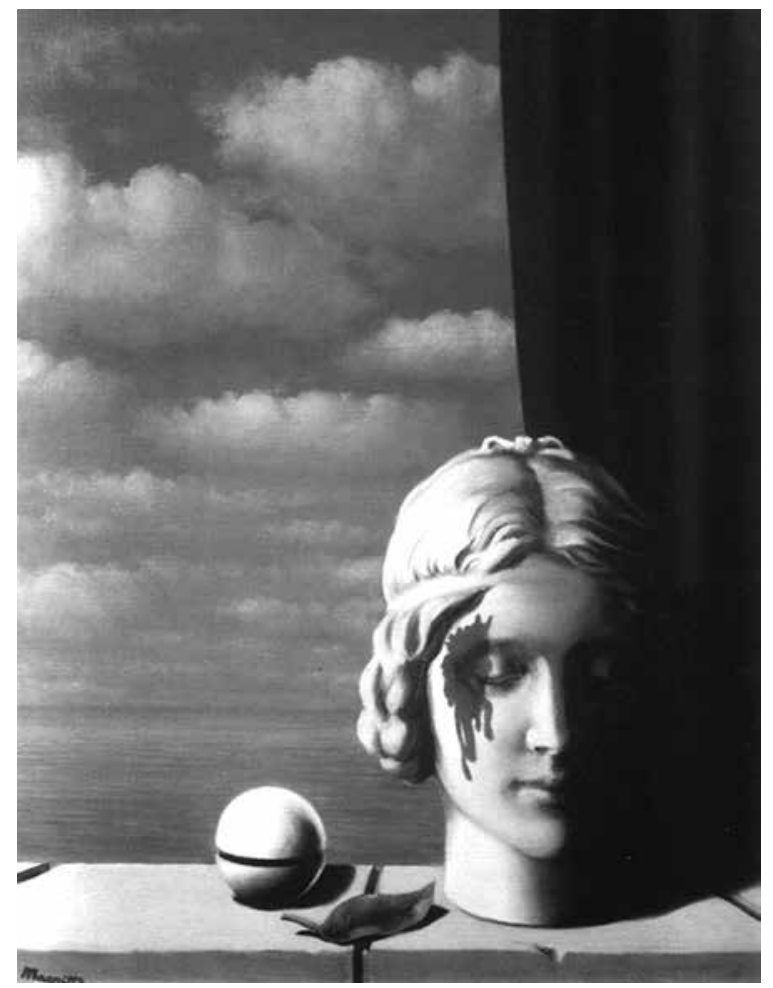

Rene Magritte, La Memoire, $60 \times 50 \mathrm{~cm}$, óleo sobre tela. Colección del Estado Belga, 1948.

estas novelas, que refuerzan cierta representación estética de lo real, y que podemos catalogar como narrativas que juegan en ese borde indeciso de lo biográfico o autoficción, en tanto que Sujeto contado es un Sujeto ficticio (Scarano, 2007).

La contundencia, la efectividad y el estatuto de credibilidad que cargan los relatos testimoniales, tan difundidos a partir de los procesos democráticos de los últimos treinta años, expresados en la "revaloración de la primera persona como punto de vista" son, al decir de Beatriz Sarlo, "pasos de un programa que se hace explícito porque hay condiciones ideológicas que lo sostienen [...] el giro subjetivo [...] que se concentra sobre los derechos y la verdad de la subjetividad"1 ${ }^{\prime 2}$ El relato de la primera

1 El término giro subjetivo lo emplea la autora en alusión y, tal vez, como réplica del giro lingüístico que atraviesa las ciencias humanas y sociales a partir de los años setenta. 
persona que atestigua, carga un potencial de componente ético: “... su carácter extremo es una especie de blindaje que lo rodea convirtiéndolo en algo que debe ser visto antes que analizado. [...] ofrece un conocimiento que [...] tiene un carácter indiscutible, tanto por la inmediatez de la experiencia como por los principios morales que fueron violados." (Sarlo, 2006: 120). Mientras que en el artículo "Villa, el médico de la memoria", el crítico literario Jorge Panesi (2003) refiere un aporte sustancial, a modo de cierta matriz que bien se puede acoplar a otras exploraciones de la ficción y memoria, señala que, en Argentina, "en la franja histórica que va de 1976 a 1983, más que héroes, hombres o relaciones subjetivas, lo que hay que narrar son dispositivos, sistemas, jerarquías infinitas, máquinas", y destaca cómo...

la primera persona narrativa del médico Villa instala una perspectiva, [...] toda perspectiva es un intento por sujetar lo múltiple, o por amoldar las heterogeneidades de las que ella misma está formada. La forma saliente de una perspectiva radica en la distancia o las distancias múltiples que evoca, en esa suerte de no coincidencia con aquello que narra y también consigo misma. (Panesi, 2003: 13, 16).

Se trata, entonces, de volver a pensar la subjetividad en relación, en devenir, dentro o en contraste de horizontes y flujos culturales, y tomar también prestado de Panesi (2003) el concepto de sedimentos de la cultura, como aquello que se trae, lo incrustado en el ser, el recuerdo de una zona, de otro tiempo, que no pertenece a la franja histórica de la perspectiva cultural del momento narrado.

Separte de la figura, siempreinquietante, del narrador y delas variantes enunciativas en que aparece ${ }^{2}$, y cuánto se involucra de relato de vida, de biografía, y cuánto, en cambio, de la dimensión puntual histórica con su componente de carga ética. En fin, instancias de creaciones subjetivas muchas veces dispersas y móviles, y hasta reforzando mecanismos de ocultación de la identidad o identidades narrativas.

Otro tópico tiene al cuerpo como territorio de escena y sufrimiento. El interrogante que suscita es cómo transmitir experiencias aterradoras,

2 Ver: Bajtín, 1989; Todorov \& Bakhtine, 1981; Genette, 1972; Bal, 2006; Foucault, 1968, 1969 y 1971. Son autores indispensables, como punto de partida, para reflexionar acerca del enunciado, los géneros del discurso, el lugar y el desempeño del narrador y cómo se define la función de autor. 
cómo establecer distancias entre la identidad de un cuerpo que habla desde una memoria de dolor, y la necesaria enmienda del paso al cuerpo social como espacio de reconocimiento y resguardo.

Un corpus de obras literarias fue seleccionado como un primer acercamiento que dé cuenta de estrategias discursivas para incorporar registros de la historia, y del estatuto que alcanza la ficción como campo propicio de exploración para recuperar sentidos de una existencia. Algunos son relatos polifónicos que actualizan una tradición oral, organizados en una suma de fragmentos, con personajes traslapados que hacen de la ficción el medio para dilucidar una verdad o testigos que permiten descubrir el secreto de una historia negada. Pero hay algo más, ciertos núcleos motores, trazos y gestos en reconocimiento con procesos culturales que permiten establecer diálogos y dar cauce para volver a visitar estos relatos desde otro lugar, iluminar una puesta de sentidos que no había sido atendida, ver el revés para alcanzar cierta comprensión ética. Por lo cual, retomo esos dispositivos institucionales de los que habla Panesi y hago extensiva a las obras literarias la metáfora de máquinas narrativas.

Sirve referenciar algunas novelas ya incorporadas a la tradición testimonial como Operación masacre (1957) de Rodolfo Walsh y La noche de Tlatelolco (1971) de Elena Poniatowska, ambas se pueden leer en espejo porque, entre otras, hacen ver la máquina de la corrupción y de la muerte. Al igual que las dos primeras novelas de Ricardo Piglia: Respiración artificial (1980) y La ciudad ausente (1992), textos que se replican entre ficciones paranoicas y máquinas de la memoria, como espacios nunca cerrados para reiterar el homenaje a cierta tradición literaria. Mientras que dos textos más recientes: La travesía (2001) de Luisa Valenzuela y Demasiados héroes (2009) de Laura Restrepo, intentan recuperar identidades silenciadas en tiempos de una Buenos Aires ominosa, que reproduce, como máquina del miedo, vacíos y desapariciones. $\mathrm{Y}$, por último, dos novelas que se leen con los registros, en proceso creciente, de la escandalosa máquina burocrática del Estado represor de la última dictadura de Argentina (1976-1983), Villa de Luis Gusmán, la cual, a partir de un personaje de la medianía, traza con fuertes cuotas de desidia una genealogía del miedo; y Dos veces junio (2002) de Martín Kohan, con otro homenaje que más que un reconocimiento es la afirmación de un legado, la herencia de otra de las impecables prosas de la literatura argentina. 


\section{La literatura, entre ficciones paranoicas y máquinas de la muerte y la memoria}

Si bien, para este tópico, se parte de una elección sesgada, hay novelas imprescindibles para consultar la tradición de acercamiento de la literatura con la historia, de la ficción con el testimonio. Textos marcados por esta simbiosis los encontramos visitando las prosas de Rodolfo Walsh, con Operación masacre; y de Elena Poniatowska quien, con La noche de Tlatelolco, nos deja estampado su nombre como muestra insoslayable de esa tradición, a pesar de la variedad de incursiones en las que se destacan sus dotes periodísticas. No es intención detenerse en esas obras ya conocidas de la literatura latinoamericana, sino sólo señalarlos como referentes literarios que han elegido procedimientos de escritura afines que refieren a la mediación de un narrador testigo, narrador periodista, para el caso de la novela de Walsh, y con Poniatowska, la presencia de un escucha oculto que pone en escena una suma de fragmentos de testimonios, de crónicas, relatos de quienes vivieron los días previos y el infierno de la matanza de Tlatelolco.

En suma, estas obras más que por la implicancia social y el impacto histórico que siguen teniendo se definen por el uso de modulaciones literarias que han logrado dejar huellas y señalar caminos de escritura posibles para recuperar la memoria y constatar una denuncia. La elección que comparten al desplazar el narrador hacia el relato del otro (Piglia, 2001), ya sea un investigador, un periodista que "conjetura" y ordena esos testimonios (Romano, 2000), o el darle lugar a muchos testigos y voces que parecerían reconstruir, en esas versiones, acontecimientos vedados y traer así la verdad, no es otra que instalar un estatuto de veracidad fuera de la fábula. Es decir, quien narra se retrae, le da la voz a otro y al reforzar la relación de la ficción con la recuperación de la verdad, la literatura adquiere un potencial ético, es tributaria de una historia, trabaja con la inmediatez, con valores. En fin, atrapada en un discurso apodíctico se inscribe dentro de una tradición que usurpa: de reflexión asertiva (Barthes, 1967).

Mientras que en otro tiempo, en 1980, se publica Respiración artificial de Ricardo Piglia ${ }^{3}$, novela que se lee en ese contexto de la última dictadura en Argentina y que vislumbra otras manifestaciones de la

3 Para profundizar en algunos aspectos de este apartado remitirse a: González, 2008. 
dinámica cultural. Representa, además, una muestra de todo el universo que hace posible la literatura cuando se atraviesan fronteras sin ningún miramiento, auténtica "ficción crítica" al decir de Nicolás Rosa (1993). Novela polifónica que construye sentidos sobre el entrecruzamiento de tramas, explorando géneros y mezclando registros en el discurso, desde epístolas, fragmentos de un diario, hasta restos de archivos históricos, con uso de apócrifos y citas.

La entrada al texto ubica al lector en un tiempo demasiado alusivo: abril de 1976, a días del 24 de marzo, fecha del golpe militar dado en Argentina por la Junta compuesta por representantes de las tres fuerzas, Videla, Massera y Agosti. También considerada novela de iniciación para Emilio Renzi, personaje característico del universo pigliano que adquiere una presencia contundente, en particular, en la primera parte del relato, y se define por buscar una historia oculta de su tío Marcelo Maggi, con quien mantiene correspondencia, con quien nunca se encuentra y quien, finalmente, lo coloca en una búsqueda de dimensión filosófica y existencial bastante apegada al presente sombrío de esos años en Argentina.

Finalmente, además de la reflexión histórica, de los vacíos de un presente innombrable, de cierto itinerario intelectual que el narrador traza como designio fatal desde el siglo XIX y enlaza con la generación que vendrá de los desaparecidos, la memoria define y concentra la dinámica de la novela y es el nudo que permite el encuentro de personajes y tramas.

En la siguiente novela, La ciudad ausente, un narrador experto que se mueve por detrás da lugar al cronista Emilio Renzi, quien, ahora, es periodista y trabaja en el diario El Mundo. Tiene un rol fijo, no se traslada, su función es registrar, es el que apunta y a veces narra. Aparece y desaparece, sin ser el personaje principal; dentro del concierto de voces del relato, su presencia es contundente. La réplica la concentra el protagonista, Junior, aunque Renzi es quien le dice lo que debe hacer, quien lo encamina hacia los lugares y sugiere pistas para buscar la grabación del "último relato conocido de la máquina" (Piglia, 1992: 30)",

4 Se refiere a la grabación de un relato del horror, de alguien que no tiene palabras para nombrarlo (Se recuerda que en la novela Junior se aventura en la búsqueda de la máquina transformadora de historias, que se encuentra en un extraño Museo. La novela, al igual que la ciudad donde se cruzan las intrigas como los relatos, son construcciones laberínticas, misteriosas y fragmentadas. Y es, por sobre todo, una ficción política y una obra marcada por el homenaje a Macedonio Fernández). 
que le llegó a Renzi, testigo y mentor de la historia. Quien, ahora, sabe más, escucha, reflexiona y más que duplicar las versiones, las ordena, las traduce, como si existiese un recorrido inevitable por donde transitarán esos relatos. La novela en sí es una máquina de reproducción de réplicas de sentidos, fragmentos de relatos clandestinos que se entrecruzan o se trafican en una ciudad que condensa espacios inacabados donde se atrinchera la memoria. La ciudad, entonces, como cuerpo por descubrir, como bazar de imágenes y territorios, subterfugios con escalas alucinantes entre altillos y subterráneos, espacios de los suburbios, perdidos y transitados, y, por eso mismo, reales. Mientras que una máquina (mujer máquina), que atesora y traduce los relatos que circulan, es el pretexto para introducirnos en los laberintos de una descomunal ficción paranoica. Auténtica maqueta que contiene a todos los personajes y obsesiones de una tradición literaria, en la cual se inscribe Piglia. Así desfilan periodistas, inventores y científicos obsesivos, cronistas detectives, asesinos, prostitutas y mujeres enigmáticas que leen el futuro, y siempre presente la figura del escritor por excelencia, Macedonio Fernández y el eterno homenaje a su amada Elena.

\section{Identidades en conflicto}

Laura Restrepo y Luisa Valenzuela reafirman en su poética huellas de una intimidad y marcas de autoficción, en las respectivas novelas: Demasiados héroes (2009) y La travesía (2001). Son relatos que hacen de su prosa una búsqueda que excede los espacios de memoria e intimidad de la voz narrativa e invitan a "la ilusión de un intercambio que remeda la confidencia" (Scarano, 2007: 85). En La travesía se construye sobre desplazamientos de discursos que atestiguan, de confesiones, diálogos de una narradora que saca a luz una verdad y de la exacerbación de relatos, caos temporal y espacial, hasta llegar a formas de inmersión en la realidad en función de potenciar un referente a partir de la mezcla de géneros y la construcción de una escritura en fragmentos. La falta de acomodamiento entre autora/narradora/personaje se manifiesta y se replica en la dificultad, siempre presente, de incorporar la experiencia propia como temática y lo irreproducible de la misma. La inadecuación entre lo pasado vivido y lo imaginario de toda creación. Son narradoras que exploran y explotan esos inconvenientes de una falta de control que se espera de quien narra: sujeto pleno; a diferencia del ficticio, el narrado, sujeto diseminado, disperso, porque "si el sí mismo está del lado de lo 
fijo, de la imagen, de lo acabado, del estereotipo, el yo está abierto al juego, a lo indecible, a lo inacabado, al biografema" (Barthes, 1978; Robin, 2005). Y lo que parece una dificultad se muestra, se salda y se resuelve en el lenguaje mismo, como en la vida la connivencia de las contradicciones.

Ambas novelas, desde un presente narrativo, intentan traer un pasado para recuperar historias de vida en el Buenos Aires de la dictadura, eran tiempos de miedo y de persecución y en ambas hay recuerdos de hombres que guardan secretos. En La travesía, dos hombres: F de Facundo y Juancho, contrastan en la memoria de una narradora que no se esconde ni reclama redención ante la angustia. Al contrario, trae los fantasmas y pone el cuerpo. Rabia y dolor alternan en recuerdos de hombres tan distantes entre sí y, sin embargo, ligados a ella, ahora irreconocible en el tiempo. Cómo conciliar esas dos fuerzas, en quién reconocerse si cabe quedar de un lado, pero escarbar en el abismo de las pasiones es como descarnarse y la narradora asume el reto. Con Juancho compartió, además de la juventud, una aventura amorosa, tiempos de estudio en la facultad y más de un secreto cómplice. Si bien hay una temporalidad para sacar el dolor de un pasado y "sacar a luz lo sucedido [...] con su correlato material: lugares, sitios, objetos, restos, huellas" (Arfuch, 2008: 164), la narradora, sin embargo, insiste en la necesidad de "presentificar la ausencia" (168) como gesto político de denuncia siempre abierta ante la desaparición forzada, tal vez como respuesta por todos esos vacíos de la memoria. Ella, más que detenerse en representar cómo era vivir en dictadura, asume el riesgo de enfrentar la emoción y se reconoce en el silencio ante la sospecha de ese arrebato atroz de un querido amigo, borrado del lugar como no fue borrado de su memoria y ahora, en otro tiempo y espacio, el duelo se impone como afirmación de una culpa. Es una narradora que se ausculta, casi se libera del remordimiento.

Mientras que con Facundo Zuberbuhler es otra la relación, opuesta, tirante, casi de resistencia, pero siempre ella cediendo y cayendo en las manipulaciones de esa figura dominante que cancela sentidos con palabras que ordenan, así como cancela las puertas y la sumerge en un encierro que ahoga y espanta. La narradora insiste en no callar, algo de desidia envuelve al Ser que fue, algo de ignominia, sin duda. Así, la presencia de F Facundo, en todo el relato, siempre es un presagio del horror que se vislumbra. Cada palabra, más que protegerla, la oculta para que no vea, que es como obligarla a que no sienta, a que no sepa. La escritura se elige como camino certero para desandar laberintos donde 
el Ser se arrincona para pertrecharse y defenderse, es en el relato como espejo donde la narradora intenta mirarse nuevamente, no para volver a ser lo que fue, menos para negarlo, sino aceptarse en ese devenir del Ser. También ella fue ese tiempo ominoso, y en el reconocimiento hay una tabla de salvación. Es en el lenguaje donde ese devenir se pone en escena, el acontecer del Ser así como no puede redimirse no puede recuperarse, sólo el relato puede dar cuenta de una secuencia temporal; y la ficción, la novela, es el marco para contener a esa otra/otredad, que la narradora fue y sigue siendo. La escritura es el espacio de recomposición del Ser fragmentado por experiencias irrepetibles, como son irreductibles en la realidad. La palabra que habla organiza el sentido y llena el vacío (Blanchot, 2005).

Mientras que en Demasiados héroes, de la escritora colombiana Laura Restrepo, también una narradora: Lorenza / Lolé, busca junto con su hijo Mateo sentidos y respuestas de una historia de militancia clandestina que vivió en la dictadura argentina junto con Ramón, alias Forcás, padre de Mateo. Son otros los procedimientos de escritura para traer esa historia, hay un esfuerzo de la narradora para referirse a sí misma, cuando era Aurelia, y la voz se distancia más: dijo ella es el código que coloca al lector en esa identidad pretérita, donde la dimensión heroica parece sobresalir. Y la narradora se pierde en esa voracidad de datos, de compañeros, militantes del partido (PST, Partido Socialista de los Trabajadores, de tendencia troskista), de fechas, vivencias de la época de la clandestinidad, y aclaraciones de los seudónimos o nombres de guerra (Restrepo, 2009).

En fin, se esfuerza por dar cuenta de lo sucedido, dimensión sólo explicable, como señala Beatriz Sarlo, por "un rasgo político-cultural más profundo que se encuentra en los momentos de giro ideológico" (2006: 156), que tiene el epicentro en la década setentista. Los años setenta vienen cargados de cambios y revoluciones, y el espíritu de gesta para dar ese giro es el que impera, por ende los actores colectivos son los que lideran.

El Buenos Aires que pinta Lorenza (cuando era Aurelia) queda estampado en cada código de época. Parece una ciudad que respira conspiraciones, y cada bar o café (La Biela, Las Violetas), o pizzerías (Los inmortales, Banchero), cada sitio, calle o pasaje (El puerto: los docks, el barrio de Barracas, el pasaje Coronda en el barrio de Caballito, la calle Lavalle, la ciudad de La Plata, Bariloche, entre otros), tienen grabada su 
impronta de algún acto peligroso, de un hecho transgresivo, de riesgo, de quienes se mueven en el borde, en el filo de la muerte. Por eso, el tono está cargado de nostalgia por la pérdida de los tiempos de juventud, cuando todo parecía posible de realizarse. Es una época de fuerte sesgo colectivo. Nada mejor que la caracterización que realiza Beatriz Sarlo sobre esos años, en alusión al libro testimonial de Miguel Bonasso ${ }^{5}$, El presidente que no fue. Así define esa época:

Los setenta son juvenilistas [...]. El juvenilismo de los setenta se apoya en el sentimiento de inminencia: se aproximan grandes cambios, que exigen tareas gigantescas por su riesgo físico y su osadía [...]. El ritmo de la política [...] exige personajes jóvenes. La idea de inminencia es afín con este despliegue de energía juvenil. (2006: 156-157).

Con Demasiados héroes se penetra en otra de las ciudades latinoamericanas de esos años. Buenos Aires es una de éstas, es otro escenario más de afectividad compartida, otro de los sitios donde "la desmesura y la soberbia se explican también por la velocidad con que se creyó que los deseos se convertían en actos políticos y los actos políticos transformaban radicalmente la realidad" (Sarlo, 2006: 157). Es un texto sin desvíos ni pliegues, una escritura marcada por cierta intencionalidad, por una narradora que se esfuerza por sacar a luz y por exacerbar los detalles, por ende se aleja del discurso de ficción y se acerca al de una investigación periodística. El detalle atestigua, prueba que eso existió; el esfuerzo por representar hasta los olores hace de los hechos experiencias transmitidas, "la verdad sobre todo está en la repetición de casi el mismo corpus de detalles" (Sarlo, 2006: 154).

Finalmente, es una escritura con cierta carga de un discurso apodíctico, que asevera y no deja lugar a la inmersión cómplice del imaginario "donde la historia se vuelve pletórica no de sentidos sino de detalles" (Sarlo, 2006: 152). Es otra confrontación de esta escritura testimonial, donde lo autobiográfico emerge como lo cotidiano, dando lugar a formas de tratamiento de la memoria que, según el razonamiento de Leonor Arfuch: "más allá de las coordenadas de la coyuntura política [...], es la

5 En este texto, Miguel Bonasso, periodista y escritor, recupera la historia de los años previos a la dictadura militar de 1976. Años que lo tienen como actor del proyecto político que, por poco tiempo, triunfa y lleva a ocupar la presidencia a Héctor J. Cámpora durante pocos meses, en 1973. Ese legado marca el espíritu de la época. 
cualidad del 'ser común' la que aparece a menudo enfatizada, los rasgos de carácter, los sueños, proyectos e ilusiones de aquellos que tenían en aquel tiempo su misma edad" (2008: 168).

Pero, también, es un texto que está minado de guiños al lector con reconocidas marcas autobiográficas: la narradora, Lorenza, es una reconocida escritora colombiana que fue periodista, trabajó como corresponsal en varios países y vivió durante la dictadura en Argentina. En fin, escrituras en espejo, recitados de una vida que, como bien señala, "necesitaba ponerle por fin palabras a esta historia hasta ahora marcada por el silencio. [...] porque pasado que no ha sido amasado con palabras no es memoria, es acechanza" (Restrepo, 2009: 234).

Textos, finalmente, con fuertes registros de autoficción. En la novela de Luisa Valenzuela, la aventura se abre y no se limita a viajes de una vida en ciudades como pieles que visten emociones, hay una subjetividad que se interroga, pero desde su posteridad. Hay un espacio, aquel Buenos Aires del miedo que hay que recomponer al igual que "una vida agujereada", recordando a Barthes. Es, por último, una narradora que no busca piedad, se reconoce al desandar el viaje tortuoso de toda escritura. Mientras que, en Demasiados héroes, más que sutilezas e introspecciones en alguna búsqueda interior, se atestigua con datos, fechas, pruebas de una narradora que vuelve al lugar de los hechos, pero al Buenos Aires actual, parecería que la voz narrativa se potencia, no para recuperar una verdad, sino para constatarla. Y un plano sobresale en esta novela, de una escritura que como sobreimpresión intenta revestir a aquella Buenos Aires de la dictadura con las fibras, el ánimo y la fuerza seductora de los momentos de una juventud intacta, como una postal congelada en un tiempo homogéneo.

\section{La máquina burocrática en marcha o la genealogía del miedo}

En 1995 se publica Villa de Luis Gusmán, novela que sitúa el referente en lo que será la antesala del terror, los meses previos al golpe de Estado de 1976 en Argentina, dado por la última dictadura de Videla, Massera y Agosti. Construcción literaria que pone en escena espacios cargados de simbolismo y nefastos augurios, como el Ministerio de Bienestar Social, lugar donde se gestó la maquinaria de persecución y muerte que tenía en el figura de López Rega a su principal ideólogo. Si, de acuerdo 


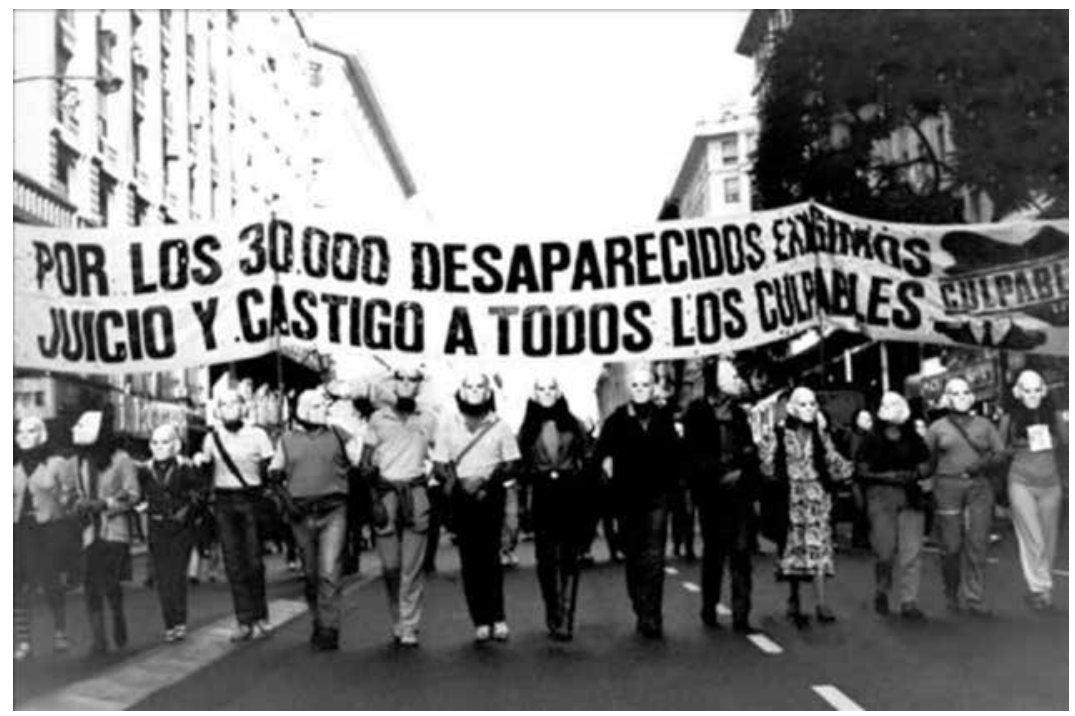

Madres de Plaza de Mayo. Foto: Archivo. EFE. 1977.

con Panesi, "la primera persona narrativa del médico Villa instala una perspectiva" (Panesi, 2003: 16) que se define por la distancia donde se juegan dos dimensiones, la autobiográfica y la historia con su potencial ético, el médico Villa condensa una amalgama de medianía, desidia y subordinación que adquiere la fuerza de una identidad colectiva. Entonces, las analogías se desprenden: cuántos "Villas", cuántos médicos o especialistas de la salud, segundones, revoloteando como moscas, amparados en la precisión de las órdenes para obedecer, fueron testigos, observadores inertes, cómplices del tormento de otros cuerpos, de secuestros, de torturas. El engranaje de la estructura reproductiva los protege, pero también los define porque...

la máquina burocrática [...] necesita de un deseo y lo produce: el deseo de burocracia o de ordenada administración del mundo [...] deseo que se confunde con el deseo de dependencia: se quiere depender de la estructura y se la ama [...] la máquina burocrática produce un mundo de jerarquías [...] estar arriba o estar abajo, a la altura o a la caída. (Panesi, 2003: 19-20)

Así, la máquina de la muerte se acopla con la retórica organicista 
del momento ${ }^{6}$, porque, como bien señala Panesi, ambos, la medicina y los militares, tratan con cadáveres, se ocupan de organismos. Pero parecería que el autor deja un escape de redención para Villa, aunque la sistematicidad va más allá que el carácter y gana el burócrata, la vocación por el registro y el informe minucioso de esas atrocidades sobrevive atesorado en Villa, dejando abierta la puerta para pasar al otro lado: al testigo con pruebas que rescataría escritos de la memoria.

Años más tarde, Martín Kohan publica Dos veces junio (2002). Novela que retoma el diálogo abierto por Luis Gusmán. Homenaje evidente de Kohan, quien le reserva la entrada al texto recordando los agoreros trágicos del mes de junio para la historia argentina. Por otro lado, también simetrías de poéticas que se establecen -ante la elección de construcción fragmentaria del texto, elección de relatos enmarcados a dos tiempos, en el mismo mes de junio-, con otra de las impecables representaciones del horror en la tradición literaria latinoamericana, precisamente en el cuento "Simetrías" (1993) de Luisa Valenzuela. Referente inevitable que deja estampado en un contrapunto siniestro sentidos de experiencias aterradoras. Parafraseando a Beatriz Sarlo, son textos ubicados como mojones en el mapa siempre incompleto de la literatura, entendida como “actos de memoria" (Sarlo, 2006).

En Dos veces junio no se conoce la identidad del narrador, ni hace falta conocerla, la reemplaza la prestancia de una construcción que coloca al lector ante la familiaridad de alguien tan anónimo como contenido en una reconocida subjetividad colectiva. Quien habla es un conscripto, soldado raso, "colimba" (denominación popular que cubría a todos aquellos civiles jóvenes que debían cumplir con el servicio militar, que era obligatorio, en aquel tiempo). Si con la novela de Gusmán estamos ante la antesala de la dictadura, con el texto de Kohan, en cambio, nos sumergimos en pleno auge del terrorismo de Estado. Hay dos momentos en este último relato, dos dimensiones temporales claves durante la dictadura argentina. Junio de 1978 con el telón de fondo del Mundial de fútbol, y junio de 1982, fin de la Guerra de Malvinas. Dos espacios marcados por diferente intensidad circunscriben la intriga. El

6 Son variadas las referencias que se dan en los discursos institucionales que definen a la sociedad como cuerpo, órgano que está enfermo, que ha sido atacado por la subversión y que hay que extirpar el mal para curar. Las manifestaciones del discurso autoritario fueron estudiadas desde perspectivas semióticas y de la sociología de las comunicaciones, en particular. 
primero, como pantalla de una situación triunfalista que se palpa en el mundial, queda, en un segundo momento, literalmente hundido ante la derrota de la guerra de Malvinas como corolario de la catástrofe para la dictadura.

Si con el personaje Villa, como señala Panesi, se construye una perspectiva que se explica más por los "sedimentos", materiales culturales incorporados, adosados en Villa de su historia anterior que hacen del mismo alguien que se define y dice más por el horizonte cultural que lo contiene. En la novela de Kohan se diluye la subjetividad y toda la narración parece alegorizar tiempos donde los "sedimentos", al modo de resacas culturales, determinan los momentos sombríos. Texto que logra captar y mantener en registro esa tensión insostenible que significa la representación de todo mal, porque al preguntarse por lo que trae la memoria, Leonor Arfuch sostiene que...

al recordar, se recuerda una imagen -con toda la problematicidad de lo icónico: el dilema de la representación, su relación intrínseca con la imaginación- y, por ende, su debilidad veridictiva y la afección que conlleva esa imagen. ¿Qué es entonces lo que "trae" con más fuerza al presente el recuerdo, la imagen o la afección?, ¿los hechos o su impronta en la experiencia? (2008: 163)

Ambos textos nos traen la afección, pero no el sufrimiento descarnado, sino que penetran en el umbral (de umbra/ umbrío) de lo indecible.

Y si Villa, como testigo, pareciera acceder a una redención, en cambio, la voz colectiva del soldado en 1978, y ex soldado en 1982, suena como murmullos siempre latentes de una sociedad sesgada por el autoritarismo. Así, Dos veces junio retoma la posta que dejó Villa, es otro capítulo de un relato que pone la mira del lado de la intolerancia. Aquí el médico es otro, el doctor Mesiano (con grado militar), a quien le presta servicios de chofer el soldado raso, y bien podría haber sido, más que colega, jefe de Villa. Y se refuerza en la iteración la metáfora que despliega la conjunción militar-médica (matar, extirpar, limpiar el mal es curar el organismo social) como rueda de una "genealogía del miedo".

Vale, incluso, destacar como procedimiento de construcción fragmentaria del relato, la sensación paranoica ante la exacerbación en el racconto $^{7}$. La entronización de los números distancia lo atroz hacia otro 
plano. Se trata de ordenar los elementos, jerarquizar las competencias y jurisdicciones, contar las horas y hasta los segundos en la sesión de tortura, los números, kilómetros, litros de combustible, medidas de peso y tipos de balanza, entre otros. En fin, la obsesión por el detalle, por las preguntas bien formuladas, sin errores ortográficos, por el comportamiento sin desmesura, por el control: responder y actuar como subordinado, todo hasta la corrección y la eficiencia; también se miden por la escala que se nivela ante la ausencia de reacciones. Sino, casi imposible parecería sostener un relato que a las pocas líneas instala una pregunta "ilegible", como señala Sarlo, que guía la intriga: “¿A partir de qué edad se puede empezar (sic) a torturar a un niño?" Cuestión que "sin el control artístico, esa pregunta inicial impediría construir cualquier historia, porque la escalada del horror la volvería intransitable, obscena" (2006: 164).

Sin embargo, es posible ahondar y transitar esos horrores gracias a la prestancia literaria, debajo de esa estructura otros registros entrecruzan historias, rastros de un tiempo, voces entrecortadas, significantes de una época oscura, en fin, fragmentos que se disparan y hacen ver lo que está oculto: los centros clandestinos de detención, la tortura sistemática para quebrar a una "detenida/desaparecida", la apropiación de hijos de desaparecidos por parte de los represores, la complicidad, la desidia, la perversión de una sociedad que sacrifica los jóvenes en una guerra absurda, y la insensatez, por sobre todo, de muchos "anónimos", como el soldado. Quien, finalmente, así como Villa, no puede controlar ni sentirse seguro con la "máquina burocrática" que ya no lo protege, lo mismo que le pasó a su jefe el Dr. Mesiano, quien se descubre expuesto al reconocer "que ahora se avecinan tiempos difíciles", este ex soldado, inseguro y desolado, intenta ahora lo único que le queda, lo imposible: controlar sus sueños, entender sus pesadillas.

Finalmente, volver a pensar el estatuto de la subjetividad es el detonante a poner en marcha, porque no es homogénea la constitución de la subjetividad en el discurso literario, al contrario, cada vez más variantes refuerzan el carácter móvil, en confrontación y contraste, en

7 Además, de los dos apartados de la novela: Diez del seis y Treinta del seis (Epílogo), más los tópicos que abren cada uno, todos se delimitan con denominación de números cardinales que colocan al lector ante una instancia de acertijo con la correspondiente referencia. 
formación e interjuego con las instituciones y con otros estamentos culturales. Apreciaciones que permiten ver el otro lado, el revés frágil del sujeto de la enunciación que, en algunos textos, sin perder la voz en primera persona, se esconde en una identidad no revelada y adquiere los visos de un enunciador colectivo, testigo anónimo, observador y cómplice que, sin identificarse y atrincherándose en la distancia de una voz múltiple, logra que su relato no pierda veracidad a pesar de concentrar tiempos de ignominia.

\section{Bibliografía}

\section{A. Ficción}

Gusmán, L. (2001). Villa. São Paulo: Iluminuras.

Kohan, M. (2003). Dos veces junio, Buenos Aires: Debolsillo.

Piglia, R. (1993). Respiración artificial [1980]. Buenos Aires: Sudamericana. (1997). La ciudad ausente [1992]. Buenos Aires: Seix Barral.

Poniatovska, E. (1974). La noche de Tlatelolco. México: Ediciones Era.

Restrepo, L. (2009). Demasiados héroes. Bogotá: Alfaguara.

Valenzuela, L. (2002). La travesía. Bogotá: Editorial Norma.

Walsh, R. (2000). Operación masacre. Buenos Aires: Ediciones de la Flor.

\section{B. Teoría, ensayos, textos críticos}

Arfuch, L. (2002). El espacio biográfico. Dilemas de la subjetividad contemporánea. Buenos Aires: FCE. (2008). Crítica cultural entre política y poética. Buenos Aires: FCE.

Bal, M. (2006). Teoría de la narrativa [1977]. Madrid: Cátedra.

Bajtín, M. (1989). Estética de la creación verbal (trad. Tatiana Bubnova). México: SXXI.

Barthes, R. (1967). El grado cero de la escritura. Buenos Aires: Ed. Jorge Álvarez. 
(1972). “O efeito de Real”. En: Genette, G.; Todorov, T. Literatura e Semiologia. Trad. Célia Neves Dourado. Petrópolis, Rio de Janeiro: Ed. Vozes Ltda, 35-44.

Blanchot, M. (2005). El libro por venir. Presentación de Emilio Velasco. Madrid: Editorial Trotta.

Camarero, J. (2011). Autobiografía: escritura y existencia. Barcelona: Anthropos Editorial.

García Yebra, V. (1974). Poética de Aristóteles (edición trilingüe). Madrid: Biblioteca Románica Hispánica / Gredos.

Genette, G. (1972). “Discours du récit”. Figuras III. París: Du Seuil.

González Sawczuk, S. (2008). Ficción y crítica en la obra de Ricardo Piglia. Medellín: La Carreta.

Jitrik, N. (1995). Historia e imaginación literaria. Las posibilidades de un género. Buenos Aires: Editorial Biblos.

Klein, I. (2008). La ficción de la memoria. La narración de historias de vida. Buenos Aires: Prometeo.

Panesi, J. (2003). “Villa, el médico de la memoria”. En Barrenechea, A. M. (Comp.). Archivos de la memoria. Rosario-Argentina: Beatriz Viterbo Editora, 13-25.

Piglia, R. (2001). “Tres propuestas para el próximo milenio (y cinco dificultades)". Casa de las Américas 222, 11-21.

Reyes, A. (1989). La experiencia literaria. México: FCE.

Ricoeur, P. (1983). Texto, testimonio y narración. Trans., prólogo y notas de Victoria Undurraga. Santiago-Chile: Editorial Andrés Bello.

. (1987). Tiempo y narración. II Configuración del tiempo en el relato de ficción. Madrid: Ed. Cristiandad. . (1996). Sí mismo como otro. España: Siglo XXI.

Robin, R. (2005). “La autoficción. El sujeto siempre en falta”. En Arfuch, L. (comp.). Identidades. Sujetos y subjetividades. Buenos Aires: Prometeo Libros, 45-48. 
Romano, E. (2000). “Modelos, géneros y medios en la iniciación literaria de Rodolfo J. Walsh". En Lafforgue, J. Textos de y sobre Rodolfo Walsh. Buenos Aires: Alianza, 73-98.

Rosa, N. (1993). “Veinte años después o la 'novela familiar' de la crítica literaria". Cuadernos hispanoamericanos 517-519, 161-186.

Saer, J. (1999). “La narración-objeto”. La narración-objeto. Buenos Aires: Seix Barral, 15-29.

Saraceni, G. (2008). Escribir hacia atrás. Herencia, lengua, memoria. Rosario-Argentina: Beatriz Viterbo Editora.

Sarlo, B. (2006). Tiempo pasado. Cultura de la memoria y giro subjetivo. Una discusión. México: Siglo XXI Editores.

Scarano, L. (2007). Palabras en el cuerpo. Literatura y experiencia. Buenos Aires: Biblos.

Todorov, T. \& Bakhtine, M. (1981). Le principe dialogique. París: Du Seuil. col. Poétique. 